\title{
Introduction Study of Tidal Flood Waste Management Cost in North Semarang Sub-District
}

\author{
Nandita Nur Rahma ${ }^{1}$, Maryono Maryono ${ }^{1}$, and Widjanarko Widjanarko ${ }^{1}$ \\ ${ }^{1}$ Department of Urban and Regional Planning, Faculty of Engineering, Diponegoro University, 50275 Semarang - Indonesia
}

\begin{abstract}
Tidal flood is a disaster that threatens coastal areas due to sea-level rise and land subsidence. One of the sub-districts in the city of Semarang, which is included in the tidal flood-prone area in every years, is the North Semarang Sub-District. The area of tidal flood is $55.95 \mathrm{Ha}$ and the data of estimated generation of tidal flood waste in the North Semarang Sub-District is +/- 70 tons. Lack of planning for handling waste disasters, especially for tidal flood waste, is a challenge related to environmental and economic impacts that occur at tidal flood sites. This study aims to examine the quantification of the cost of handling tidal flood waste using quantitative descriptive analysis cost accounting calculation method. The calculation is done by considering several things, namely the activity of handling waste, the need for handling waste, as well as the calculation of the cost of handling tidal flood waste. The total cost of handling tidal flood waste in North Semarang Sub-District is IDR 14,209,324,000/year or IDR $1,184,110,333 /$ month. The results of the calculation of the overall cost are then divided by the area of the tidal flood so that the unit cost of handling waste per $\mathrm{m}^{2}$ is IDR $2,117 / \mathrm{m}^{2}$.
\end{abstract}

Keywords: Disaster Waste; Environmental Economics; Tidal Flood Waste; Operating Cost; Unit Cost.

\section{Introduction}

Disasters are events or series of events that threaten and disrupt people's lives and livelihoods caused both by natural and/or non-natural factors as well as human factors, resulting in human casualties, environmental damage, property losses, and psychological impacts [1]. One of the natural disasters that threaten coastal residents is tidal flooding. Tidal flood is a disaster that occurs due to sea-level rise (sea level rise) with an average of 1 $\mathrm{m} /$ year. Besides, there is a decrease in land surface (land subsidence) due to excessive groundwater uptake of around $14.7 \mathrm{~cm} /$ year [2].

Tidal floods are physical conditions of flooding or inundation due to high tides. The condition of the coast of Semarang City changes $1.46 \mathrm{~cm}$ in height every year this is due to the rise in sea level in Semarang [3]. It can be seen that the sea surface conditions in Semarang waters that have experienced such changes have caused the impact of overflowing water or commonly referred to as tidal floode. Besides, in terms of land subsidence aspects from map observations from 2000 to 2010, the Semarang area experienced a decrease of $1 \mathrm{~cm} /$ year to 9 $\mathrm{cm} /$ year. This condition shows that the coastal area, including North Semarang Sub-District, has a high vulnerability. Research conducted by several sources states that the North Semarang Sub-District each year has a prediction of the area affected by rob, with an area of 508.28 Ha [4]; 1095,95 Ha [5]; 823,545 $\mathrm{Ha} \mathrm{[6];} \mathrm{and}$ $903.85 \mathrm{Ha}$ [7]. Addition conditions to sea level rise and land subsidence will have an impact on areas prone to flooding in the city of Semarang, especially in the North Semarang Sub-District.

Disaster waste conditions can be different as in conditions of nature and severity of disasters. The condition of tidal flood impact can cause serious problems including environmental degradation, especially inundation and waste generation. In general, standing water on land causes slow damage to submerged buildings and garbage generation can emerge and pollute the environment [8]. Disaster waste can produce large amounts of debris and waste. The volume of disaster waste from an event can be equivalent to many times the annual level of waste generation of the affected community. This volume can overwhelm existing solid waste management facilities and personnel. Improper waste management can affect the response and long-term recovery of the affected area [9]. Waste generation due to flooding is one of the frequent impacts and becomes a problem that must be dealt with effectively and effectively [10]. Waste generation due to flooding in Thailand in 2011 caused an estimated waste of 3.25 million tons [11]. Tidal flood waste can be said to be a pile of hazardous waste because the mixture of all forms of waste into one drifted or stagnant.

\footnotetext{
Corresponding author: nandytar@gmail.com
} 
Another source said that the tidal flood that occurred on the north coast of Java reached approximately 1 meter causing the majority of the environment to be inundated and caused a pile of waste [12]. One example of the impact seen is the condition of the coastal environment, especially the area of the pond being disturbed due to being destroyed by high waves swept and causing losses of up to IDR 500 million. The visible environmental impact is the piles of waste in the fish ponds owned by residents due to tidal flooding. Tidal flood disaster is a specific waste so it requires special handling that is different from domestic waste [13]. Disaster waste handling is done to clean up the affected location so that it does not cause adverse environmental impacts.

An environmental impact is a form of externalities [14]. Externalities can be understood as the costs or benefits of market transactions that are not reflected in the form of general prices [15]. Negative externalities, in this case, can be seen from the impact caused by having a bad influence on the environment. One example of the negative externalities seen around our environment is the impact of waste generation. The community is affected by unhealthy environmental conditions and the environment becomes dirty. Waste generation must be addressed immediately through appropriate and fast handling to reduce the level of negative externalities that result [16]. An assessment of the value of environmental impacts using environmental economic analysis can be done so that it can be understood the relationship between the use of resources and the environment with the resulting impact [17].

The calculation of environmental economic value can be done using the cost accounting method. Cost accounting is a decision-making framework in the form of a systematic approach to identifying, adding up, and reporting actual costs [18]. Aspects that need to be considered in calculating the accounting costs of handling flood tidal waste are taking into account the activities of handling waste, the need for facilities, to the calculation of unit costs incurred. Types of costs based on the identification of needs will be divided into two types as a whole, namely direct costs and indirect costs or analysis of direct costs and indirect costs [19].

The absence of appropriate handling related to tidal flood waste is a negative externality in the form of environmental pollution and environmental economic costs that are borne. Based on this, it is understood that the need for follow-up from the government related to disaster waste handling, especially tidal flood flooding. In addition to this, the costs incurred during the activities of handling waste, especially tidal flood waste, have not been further studied, particularly in the coastal areas of the North Semarang Sub-District. The application of environmental cost accounting in waste management is done by taking into account several cost items including collection fees, transportation costs, and up to disposal costs [20].

One important factor in disaster prevention, which is an understanding of the amount and characteristics of disaster waste [21]. The important thing after knowing the estimation or potential for disaster waste generation, then the things that must be considered afterward are transportation activities, land collection areas, and inventory cost requirements [22]. This function is to evaluate environmental costs and scenario costs for disaster waste handling activities. So, if the viewpoint of tidal flood waste handling with the calculation of the costs borne are combined, then a study will be obtained on the appropriate handling activities, the need for waste handling facilities, to the burden of costs incurred.

An understanding of the relationship between the impact of tidal flood waste and the costs borne by the environment will provide effective and efficient information for the Semarang City government in general, and the North Semarang Sub-District government specifically, or related parties to follow up on the issues and problems of tidal flood waste. The considerations used in handling tidal flooding ranging from activities to the needs of facilities and tools needed are different from ordinary solid waste handling, so it requires a variety of costs. Based on this, this study will produce the total costs incurred per region $\left(\mathrm{m}^{2}\right)$ in the overall handling of tidal flood waste in the North Semarang Sub-District.

\section{Data and methods}

Data collection methods in this study use primary data in the form of interviews with key informants and field observations and secondary data in the form of literature and policy studies. The analytical method used in calculating the cost of handling the flood disaster in the North Semarang Sub-District is using a descriptive analysis technique with a quantitative approach.

The main analysis method in this study uses cost accounting. Cost accounting is a detailed method of calculating costs related to the allocation of direct and indirect costs by gathering information related to environmental, social, and economic conditions to produce alternative financing. The quantification analysis method uses consideration of the analysis of tidal flood waste handling activities, the need for tidal flood waste handling, and the calculation of the overall cost of handling tidal flood waste.

The stages of analysis in this study were carried out by processing data related to waste handling activities. The data consists of rob area data and waste generation using joint research data and transportation route data and stages of waste handling activities. From this data, it is then used as data in calculating the need for handling tidal floodes.

\subsection{Data of tidal flood waste management in north semarang}

Waste handling/collection activities are carried out to transport and reduce the environment from the risk of waste generation containing various types of dangerous goods and debris. Waste collection is carried out at the same time as an effort to clean up from the affected location to temporary landfills [23]. The second activity for handling waste disasters is the collection of waste at 
the temporary site. The function of this process is to facilitate the collection of waste before being taken to the landfill. Temporary sites are locations for loading and unloading waste. The collection and transportation process requires facilities, tools, and workers to be adjusted [24]. The activity of tidal flood waste management in North Semarang Sub-District considers several things through the results of joint research including, namely:

(a) The area of the tidal flood area in North Semarang Subdistrict is $55.95 \mathrm{Ha}$ with locations in Tanjung Mas Village, Bandarharjo Village, and Panggung Lor Village; and

(b) The estimated generation of tidal flood waste in the North Semarang Sub-District is 70,095.26 or +/- 70 tons, with details of estimated waste generation per land-use type as follows:

Table 1. Waste Generation based on Land-Use

\begin{tabular}{|l|c|c|}
\hline \multicolumn{1}{|c|}{ Land-Use } & $\begin{array}{c}\text { Estimated Waste } \\
\text { Generation (Kg) }\end{array}$ & Result (Ton) \\
\hline Industrial/Port Area & $5.948,191$ & 5,9 \\
\hline Settlement Area & $4.910,4094$ & 4,9 \\
\hline Coastal Area & $44.127,134$ & 44,1 \\
\hline Pond Area & $15.109,5243$ & 15,1 \\
\hline \multicolumn{1}{|c|}{ Total } & $70.095,26$ & $+/-70$ \\
\hline
\end{tabular}

Based on that results, an analysis of the transportation route with the existing route is then carried out to determine the waste transportation route. The transportation route has 21 collection points in the tidal flood area that has a pile of waste. The transportation route uses the location and existing route which then empties into the temporary sites located at the Panggung Lor temporary sites. The farthest distance from the collection point to the location of temporary sites is $+/-5$ $\mathrm{km}$.

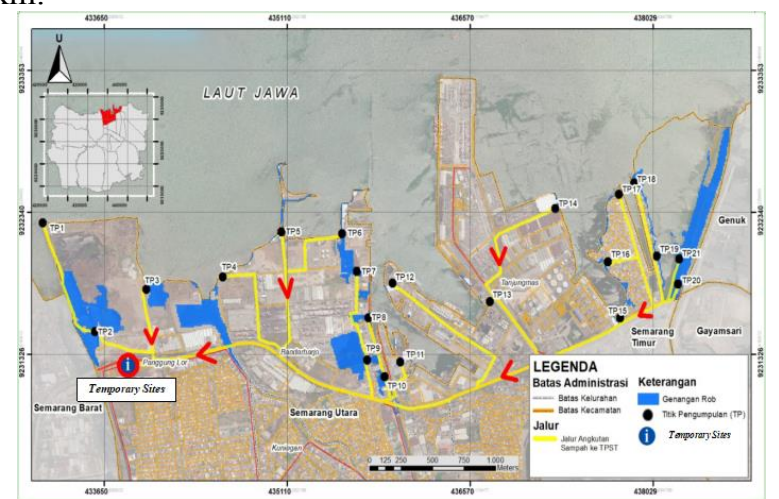

Fig 1. Map of Tidal Flood Waste Transport Routes in North Semarang (Analysis Results, 2019)

Tidal flood waste handling activities are carried out in 2 stages, which function to clean the location of tidal flood waste to reduce environmental impacts, namely:

(a) Collection of waste in the location of the tidal floodotic waste generation by taking into account the frequency (rotation) of collection in one day is approximately 6-7 visits; schedule of collection conducted in the morning, afternoon and evening; the pattern of waste collection by picking up waste at the site of waste generation and transported to the location of temporary sites; as well as the need for collection facilities ranging from the needs of vehicles and heavy equipment, operational needs of workers, cleaning tools, tools, emergency needs, to first aid kit; and

(b) Transporting waste to the location of temporary sites (TS) is useful for moving waste collected from the waste collection location to a temporary collection site, for then moving the waste to a device or vehicle that will transport it to the landfill.
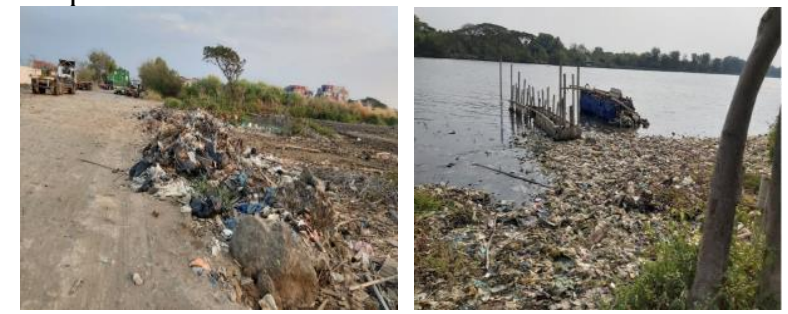

Fig 2. Tidal Flood Waste in North Semarang (Field Observation, 2019)

In the activities of turning and transporting waste needed workers who move in the field. The worker works according to his function, namely:

(a) Workers in collecting activities to collect waste at the location to be taken to a temporary location, consisting of vehicle drivers, heavy equipment operators, driver assistants, janitors, and transport personnel.

(b) Workers in temporary site (TS) activities are trying to improve the location of the TS and are ready to respond if an emergency occurs at the location to repair the flood tidal waste.
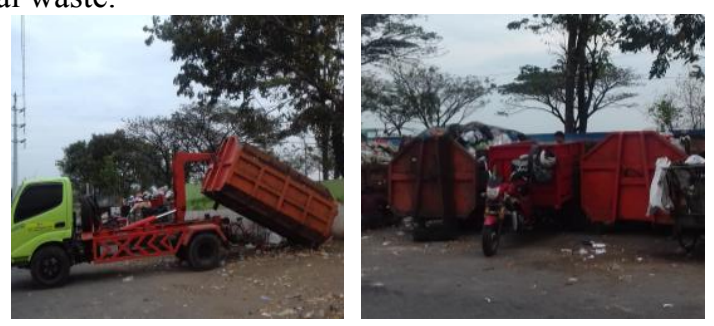

Fig 3. Waste Management Activities in North Semarang (Field Observation, 2019)

This analysis of waste handling activities will be the basis for facilitating the activities of handling tidal floods to clean. Besides that, the activity of tidal flood waste management will help to formulate the needs of tidal flood management facilities.

\subsection{Data of tidal flood waste management needs in north semarang}

The need for handling tidal flood waste consists of facilities and tools. This need is a need that is adapted to 2 important conditions, namely the condition of tidal flood response and the condition of tidal flood waste handling. Based on this, the types of needs are adjusted to the function of disaster response and waste handling functions.

The formulation of needs in this study is based on several related regulations and sources as a basic 
$[25,26,27,28]$. Based on sources from Disaster Response Equipment and Disaster Management Equipment, inventory needs consist of several types [29].

Calculation of the need for handling flood tidal waste is carried out through these classifications including, namely (a) the needs of vehicles and heavy equipment; (b) the operational needs of workers; (c) the need for cleaning tools; (d) tooling needs; (e) need for supporting equipment; (f) emergency needs, (g) first aid needs; (h) operational needs such as administration, land rent, and environmental compensation.

\section{Result and discussion}

The analysis in this study discusses the calculation of the need for handling tidal flood waste to calculate the cost of handling tidal flood waste.

\subsection{Analysis of needs calculations}

Analysis of the calculation of needs is done by calculating waste generation according to the type of land use. Things to be considered in this calculation are considerations of capacity, speed, amount of waste, collection time, and the number of attractions. Examples of calculation of needs are explained in the calculation of needs for Arm Roll Trucks in Industrial Areas / Ports.

Arm roll truck is a means of transportation with dimensions of a body measuring $6 \mathrm{~m}^{3}$ or equivalent to 1.5 tons. The arm roll truck functions to transport large amounts of waste and is equipped with hydraulic lifting equipment to raise/lower the body.

Table 2. Arm Roll Truck Capacity

\begin{tabular}{|l|l|}
\hline Capacity Description & $25 \mathrm{~km} /$ hour \\
\hline Speed & $5 \mathrm{~km}$ \\
\hline Service Range & 1,5 ton \\
\hline Capacity & 1,2 \\
\hline Compacting Factor & $+/-5,9$ ton \\
\hline $\begin{array}{l}\text { Amount of waste in } \\
\text { Industrial/Port Area }\end{array}$ & \\
\hline
\end{tabular}

Source : Analysis Results, 2019

Table 3. Waste Collection Time by Arm Roll Truck

\begin{tabular}{|l|l|}
\hline \multicolumn{2}{|l|}{ Collection Time Description } \\
\hline Collection time in location & 25 minutes \\
\hline $\begin{array}{l}\text { Container Lifting Down } \\
\text { Time }\end{array}$ & 8 minutes \\
\hline Container Lifting Up Time & 8 minutes \\
\hline Travel Time & $\begin{array}{l}(5 \mathrm{~km} \times 2 \mathrm{PP}) / 25 \mathrm{~km} / \mathrm{hour} \\
=24 \text { minutes }\end{array}$ \\
\hline Rest Time & 25 minutes \\
\hline Total & 90 minutes \\
\hline
\end{tabular}

Source : Analysis Results, 2019

Each arm roll truck has an accumulated need of 90 minutes each time. If the retrieval work period is 8 working hours, then the number of rotation that may be used is as much as:

$$
\frac{8 \times 60}{90} \times 1 \text { rit }=5,3 \text { rit } \sim 6 \text { rit }(\text { maks })
$$

So, the ration of the Arm Roll Trucks is 6 times (each schedule takes 2 times). Thus, the taking capacity with 1 arm roll truck is $6 \times 1.5$ tons $=9$ tons of waste per day with a compacting factor of 1.2. Total arm roll truck requirements:

$$
\frac{5,9}{9 x 1,2}=0,54 \text { unit } \sim 1 \text { unit }
$$

The total result of the need for arm roll trucks is 1 unit, then needed for worker details. Each arm roll truck needs 1 driver, 1 driver assistants, 1 transport worker, and 1 janitor.

After calculating based on the amount of waste generation following the type of land use, these results become the basis of calculations for the needs of workers to operate. Accumulated calculation of vehicle and heavy equipment needs including, i.e. :

Table 4. Accumulated Vehicle and Heavy Equipment Needs (Analysis Results, 2019)

\begin{tabular}{|c|l|l|l|l|}
\hline No & \multicolumn{1}{|c|}{ Vehicles } & $\begin{array}{c}\text { Volume } \\
\text { Capacity } \\
\left(\mathrm{m}^{3}\right)\end{array}$ & $\begin{array}{c}\text { Weight } \\
\text { Capacity } \\
\text { (ton) }\end{array}$ & $\begin{array}{c}\text { Total } \\
\text { Needs } \\
\text { (Unit) }\end{array}$ \\
\hline 1 & $\begin{array}{l}\text { Garbage } \\
\text { Cart }\end{array}$ & $1,25 \mathrm{~m}^{3}$ & 0,31 & 8 \\
\hline 2 & $\begin{array}{l}3 \quad \text { Wheel } \\
\text { Motor }\end{array}$ & $2 \mathrm{~m}^{3}$ & 0,5 & 19 \\
\hline 3 & Pick Up Car & $3 \mathrm{~m}^{3}$ & 0,75 & 3 \\
\hline 4 & $\begin{array}{l}\text { Arm Roll } \\
\text { Truck }\end{array}$ & $6 \mathrm{~m}^{3}$ & 1,5 & 5 \\
\hline 5 & Dump Truck & $8 \mathrm{~m}^{3}$ & 2 & 4 \\
\hline 6 & $\begin{array}{l}\text { Garbage } \\
\text { Container }\end{array}$ & $6 \mathrm{~m}^{3}$ & 1,5 & 6 \\
\hline 7 & $\begin{array}{l}\text { Garbage } \\
\text { Container }\end{array}$ & $10 \mathrm{~m}^{3}$ & 2,5 & 3 \\
\hline 8 & $\begin{array}{l}\text { Water } \\
\text { Tankers }\end{array}$ & 3000 liter & 2.94 & 4 \\
\hline 9 & Bulldozer & - & - & 1 \\
\hline 10 & $\begin{array}{l}\text { Excavator } \\
\text { PC }\end{array}$ & - & - & 1 \\
\hline 11 & $\begin{array}{l}\text { Wheel } \\
\text { Loader }\end{array}$ & - & - & 1 \\
\hline 12 & $\begin{array}{l}\text { Backhoe } \\
\text { Loader }\end{array}$ & - & - & 1 \\
\hline 13 & Forklift & - & - & 1 \\
\hline 14 & Scraper & - & - & 1 \\
\hline 15 & $\begin{array}{l}\text { Motor } \\
\text { Grader }\end{array}$ & - & - & 1 \\
\hline
\end{tabular}

From the results of the accumulation of vehicles and heavy equipment needs then used as a calculation of worker needs. Workers carrying out tasks in the activity of handling tidal flood waste include, among others, drivers, heavy equipment operators, driver assistants, cleaning workers, transport workers, and workers at temporary sites (TS). The accumulated number of needs of workers, including:

Table 5. Accumulated Worker Needs (Analysis Results, 2019)

\begin{tabular}{|c|c|c|}
\hline No & Workers & Total (persons) \\
\hline
\end{tabular}




\begin{tabular}{|l|l|l|}
\hline 1 & Vehicle Drivers & 43 \\
\hline 2 & Heavy Equipment Operators & 7 \\
\hline 3 & Driver assistants & 16 \\
\hline 4 & Janitors & 39 \\
\hline 5 & Transport Worker & 39 \\
\hline 6 & Worker in TS & 9 \\
\hline
\end{tabular}

Based on the calculation of the needs of vehicles and heavy equipment and the needs of workers, other calculations such as the operational needs of workers, cleaning equipment, tools, supporting equipment, emergency, and first aid are calculated based on the number of workers. These needs are requirements based on field functions and conditions. The results of the accumulation of all needs will be used in the calculation of costs per type of need.

\subsection{Analysis of cost requirements calculation}

The cost calculation in this study uses the results of the needs calculation analysis. The calculation of costs in handling tidal flood waste is the overall cost of the types of needs that have been identified by tidal flood waste handling activities and tidal flood disaster emergency response. The cost calculation consists of the costs for the needs of vehicles and heavy equipment, worker's salaries, worker's operations, cleaning tools, tools, supporting equipment, emergency, first aid, land rent, and environmental compensation. Costs used in handling tidal flood waste are classified in the types of direct and indirect costs.

One example of calculating vehicle costs that can be considered is the operational costs of dump trucks. Costs incurred directly for arm roll trucks are rental costs, fuel, cleaning costs, oil change costs, and engine service costs. While the costs for indirect operations are insurance costs, KIR vehicle costs, and parking fees. This cost calculation is based on need but can adjust to the time and conditions in the field. Calculation of the cost of arm roll truck costs, i.e. :

Table 6. Calculation of Arm Roll Truck Cost Requirement (Analysis Results, 2019)

\begin{tabular}{|c|c|c|}
\hline $\begin{array}{c}\text { Cost } \\
\text { Allocation }\end{array}$ & Calculations & Total Cost (per year) \\
\hline Rent Cost & $\begin{array}{l}\text { IDR } 17.000 .000 \times 5 \\
\text { unit } \times 12 \text { month }\end{array}$ & IDR 1.020 .000 .000 \\
\hline $\begin{array}{l}\text { Insurance } \\
\text { Cost }\end{array}$ & $\begin{array}{llll}\text { IDR } & 2.000 .000 \times 5 \\
\text { unit } & & & \\
\end{array}$ & 10.000 .000 \\
\hline Fuel Cost & $\begin{array}{l}15 \text { Liter/days } \\
\text { IDR } 9.800 \text { x } 15 \text { liter } \\
\text { x } 5 \text { unit x } 360 \text { days }\end{array}$ & IDR $\quad 264.600 .000$ \\
\hline $\begin{array}{l}\text { Cleaning } \\
\text { Cost }\end{array}$ & $\begin{array}{l}\text { IDR } 20.000 \text { x } 5 \text { unit } \\
\times 360 \text { days }\end{array}$ & IDR $\quad 36.000 .000$ \\
\hline Oil Cost & $\begin{array}{l}\text { IDR } 45.000 \text { x } 5 \text { unit } \\
\times 12 \text { month }\end{array}$ & 2.700 .000 \\
\hline $\begin{array}{l}\text { Machine } \\
\text { Service } \\
\text { Cost }\end{array}$ & $\begin{array}{l}\text { IDR } 1.000 .000 \times 5 \\
\text { unit } x 12 \text { month }\end{array}$ & 60.000 .000 \\
\hline $\begin{array}{l}\text { KIR } \\
\text { Vehicles } \\
\text { Cost } \\
\end{array}$ & $\begin{array}{l}\text { IDR } 2.500 .000 \times 5 \\
\text { unit } x 2 \text { times }\end{array}$ & 25.000 .000 \\
\hline
\end{tabular}

\begin{tabular}{|c|c|c|}
\hline $\begin{array}{c}\text { Cost } \\
\text { Allocation }\end{array}$ & Calculations & Total Cost (per year) \\
\hline $\begin{array}{l}\text { Parking } \\
\text { Cost }\end{array}$ & $\begin{array}{l}\text { IDR } 5.000 \times 6 \text { rit } \times 5 \\
\text { unit } \times 360 \text { days }\end{array}$ & IDR $\quad 54.000 .000$ \\
\hline & Total & IDR 1.472 .300 .000 \\
\hline
\end{tabular}

Calculation of accumulation per type of need is calculated from the number of needs and age of use of the tool or needs. Details of the calculation include i.e : a. Vehicles and Heavy Equipment Cost

The total operating costs of vehicles and heavy equipment is a recapitulation of the total costs required in the needs of vehicles and heavy equipment both direct and indirect needs.

Table 7. Vehicles and Heavy Equipment Cost (Analysis Results, 2019)

\begin{tabular}{|c|c|c|c|c|}
\hline No & Vehicles & $\begin{array}{l}\text { Total } \\
\text { Needs }\end{array}$ & \multicolumn{2}{|c|}{$\begin{array}{c}\text { Operating Cost (per } \\
\text { year) }\end{array}$} \\
\hline 1 & $\begin{array}{l}\text { Garbage } \\
\text { Cart }\end{array}$ & 8 & IDR & 379.200 .000 \\
\hline 2 & $\begin{array}{l}3 \text { Wheel } \\
\text { Motor }\end{array}$ & 19 & IDR & 1.154 .326 .000 \\
\hline 3 & Pick Up Car & 3 & IDR & 283.740 .000 \\
\hline 4 & $\begin{array}{ll}\text { Arm } & \text { Roll } \\
\text { Truck } & \end{array}$ & 5 & IDR & 1.472 .300 .000 \\
\hline 5 & Dump Truck & 4 & IDR & 1.081 .840 .000 \\
\hline 6 & $\begin{array}{l}\text { Garbage } \\
\text { Container } 6 \\
\mathrm{~m}^{3}\end{array}$ & 6 & IDR & 230.400 .000 \\
\hline 7 & $\begin{array}{l}\text { Garbage } \\
\text { Container } 10 \\
\mathrm{~m}^{3}\end{array}$ & 3 & IDR & 133.200 .000 \\
\hline 8 & $\begin{array}{l}\text { Water } \\
\text { Tankers }\end{array}$ & 4 & IDR & 941.040 .000 \\
\hline 9 & Bulldozer & 1 & IDR & 471.000 .000 \\
\hline 10 & $\begin{array}{l}\text { Excavator } \\
\text { PC }\end{array}$ & 1 & IDR & 479.400 .000 \\
\hline 11 & $\begin{array}{l}\text { Wheel } \\
\text { Loader }\end{array}$ & 1 & IDR & 504.600 .000 \\
\hline 12 & $\begin{array}{l}\text { Backhoe } \\
\text { Loader }\end{array}$ & 1 & IDR & 420.600 .000 \\
\hline 13 & Forklift & 1 & IDR & 216.480 .000 \\
\hline 14 & Scraper & 1 & IDR & 479.400 .000 \\
\hline 15 & $\begin{array}{l}\text { Motor } \\
\text { Grader }\end{array}$ & 1 & IDR & 504.600 .000 \\
\hline \multicolumn{3}{|c|}{ Total } & IDR & 8.752 .126 .000 \\
\hline
\end{tabular}

\section{b. Worker's Salaries}

The allocation of costs for worker salaries per month consists of salary allocation for workers including, for drivers, heavy equipment operators, driver assistants, janitors, transport workers, and officers on temporary sites. This salary fee is based on the Semarang City Regional Minimum Wage and interviews with relevant officers. 
Table 8. Worker's Salaries (Analysis Results, 2019)

\begin{tabular}{|c|c|c|}
\hline $\begin{array}{c}\text { Cost } \\
\text { Allocation }\end{array}$ & Calculations & Total Cost (per year) \\
\hline Drivers & $\begin{array}{l}\text { IDR } 2.500 .000 \times \\
43 \text { persons } \times 12 \\
\text { month }\end{array}$ & IDR $\quad 1.290 .000 .000$ \\
\hline $\begin{array}{l}\text { Heavy } \\
\text { Equipment } \\
\text { Operators }\end{array}$ & $\begin{array}{l}\text { IDR } 2.500 .000 \times 7 \\
\text { persons } \quad \text { x } 12 \\
\text { month }\end{array}$ & 210.000 .000 \\
\hline $\begin{array}{l}\text { Driver } \\
\text { assistants }\end{array}$ & $\begin{array}{l}\text { IDR } 1.900 .000 \times \\
16 \text { persons } \times 12 \\
\text { month }\end{array}$ & 364.800 .000 \\
\hline Janitors & $\begin{array}{l}\text { IDR } 1.900 .000 \times \\
39 \text { persons } \times 12 \\
\text { month }\end{array}$ & 889.200 .000 \\
\hline $\begin{array}{l}\text { Transport } \\
\text { Worker }\end{array}$ & $\begin{array}{l}\text { IDR } 1.900 .000 \times \\
39 \text { persons } \times 12 \\
\text { month }\end{array}$ & 889.200 .000 \\
\hline Worker in TS & $\begin{array}{l}\text { IDR } 1.900 .000 \times 9 \\
\text { persons } \quad \times \quad 12 \\
\text { month }\end{array}$ & 205.200 .000 \\
\hline & Total & IDR $\quad 3.848 .400 .000$ \\
\hline
\end{tabular}

\section{c. Worker's Operational Cost}

Worker operational costs are costs allocated for worker's operational needs as personal protective equipment and work protective equipment based on relevant standards and regulations.

Table 9. Worker's Operational Cost (Analysis Results, 2019)

\begin{tabular}{|c|c|c|c|}
\hline Needs & Calculations & $\begin{array}{l}\text { Time } \\
\text { Use }\end{array}$ & Total (per year) \\
\hline $\begin{array}{l}\text { Worker } \\
\text { Uniform }\end{array}$ & $\begin{array}{l}\text { IDR } 150.000 \\
\mathrm{x} 153 \text { unit }\end{array}$ & 1 year & IDR 22.950 .000 \\
\hline $\begin{array}{l}\text { Rubber } \\
\text { Boots } \\
\end{array}$ & $\begin{array}{l}\text { IDR } 155.000 \\
\times 153 \text { unit } \\
\end{array}$ & 1 year & IDR 23.715.000 \\
\hline $\begin{array}{l}\text { Anti- } \\
\text { pollution } \\
\text { filter mask }\end{array}$ & $\begin{array}{l}\text { IDR } 40.000 \\
x 153 \text { unit }\end{array}$ & 6 month & IDR 12.240 .000 \\
\hline Flashlight & $\begin{array}{l}\text { IDR } 50.000 \\
\times 153 \text { unit } \\
\end{array}$ & 1 year & IDR 7.650 .000 \\
\hline $\begin{array}{l}\text { Safety } \\
\text { Glasses }\end{array}$ & $\begin{array}{l}\text { IDR } 5.000 \times \\
153 \text { unit }\end{array}$ & 1 year & IDR $\quad 765.000$ \\
\hline $\begin{array}{l}\text { Safety } \\
\text { Helmet }\end{array}$ & $\begin{array}{l}\text { IDR } 30.000 \\
\mathrm{x} 153 \text { unit }\end{array}$ & 1 year & IDR $\quad 4.950 .000$ \\
\hline $\begin{array}{l}\text { Antiseptic } \\
\text { Fluid }\end{array}$ & $\begin{array}{l}\text { IDR } 15.000 \\
\mathrm{x} 153 \text { unit }\end{array}$ & 2 month & IDR 13.770 .000 \\
\hline $\begin{array}{l}\text { PVC } \\
\text { Apron }\end{array}$ & $\begin{array}{l}\text { IDR } 40.000 \\
x \quad 153 \text { unit }\end{array}$ & 1 year & IDR 6.120 .000 \\
\hline $\begin{array}{l}\text { Pockets } \\
\text { Vests }\end{array}$ & $\begin{array}{l}\text { IDR } 200.000 \\
\text { x } 153 \text { unit }\end{array}$ & 1 year & IDR 30.600 .000 \\
\hline Caping Hat & $\begin{array}{l}\text { IDR } 17.000 \\
x 87 \text { unit }\end{array}$ & 1 year & IDR $\quad 1.479 .000$ \\
\hline $\begin{array}{l}\text { Rubber } \\
\text { Gloves }\end{array}$ & $\begin{array}{l}\text { IDR } 10.000 \\
x 153 \text { unit }\end{array}$ & 2 month & IDR 9.180 .000 \\
\hline
\end{tabular}

\begin{tabular}{|c|c|c|c|}
\hline Needs & Calculations & $\begin{array}{l}\text { Time } \\
\text { Use }\end{array}$ & Total (per year) \\
\hline Headlamp & $\begin{array}{l}\text { IDR } 23.000 \\
\times 153 \text { unit }\end{array}$ & 1 year & IDR 3.519 .000 \\
\hline $\begin{array}{l}\text { Worker } \\
\text { Towel } \\
28 \mathrm{~cm}\end{array}$ & $\begin{array}{l}\text { IDR } 11.000 \\
x 153 \text { unit }\end{array}$ & 2 month & IDR 10.098.000 \\
\hline $\begin{array}{l}\text { Face } \\
\text { Protector }\end{array}$ & $\begin{array}{l}\text { IDR } 80.000 \\
\mathrm{x} 87 \text { unit }\end{array}$ & 1 year & IDR $\quad 6.960 .000$ \\
\hline $\begin{array}{l}\text { Knee } \\
\text { Protector }\end{array}$ & $\begin{array}{l}\text { IDR } 70.000 \\
x \quad 153 \text { unit } \\
\end{array}$ & 1 year & IDR 10.710 .000 \\
\hline $\begin{array}{l}\text { Elbow } \\
\text { Protector }\end{array}$ & $\begin{array}{l}\text { IDR } 55.000 \\
\times 153 \text { unit } \\
\end{array}$ & 1 year & IDR 8.415 .000 \\
\hline $\begin{array}{l}\text { Antishocks } \\
\text { Treking } \\
\text { Pole } \\
\end{array}$ & $\begin{array}{l}\text { IDR } 85.000 \\
\times 87 \text { pasang }\end{array}$ & 1 year & IDR 7.395 .000 \\
\hline $\begin{array}{l}\text { Mitten } \\
\text { Gloves }\end{array}$ & $\begin{array}{l}\text { IDR } 65.000 \\
x 153 \text { unit }\end{array}$ & 6 month & IDR 19.890 .000 \\
\hline $\begin{array}{l}\text { Waterproof } \\
\text { Watch }\end{array}$ & $\begin{array}{l}\text { IDR } 125.000 \\
\text { x } 153 \text { unit }\end{array}$ & 1 year & IDR 19.125 .000 \\
\hline \multicolumn{3}{|c|}{ Total } & IDR 215.706.000 \\
\hline
\end{tabular}

\section{d. Land Rent Cost}

The temporary sites or temporary waste collection locations are at the Panggung Lor temporary site locations with an area of $20 \mathrm{~m} \mathrm{x} 10 \mathrm{~m}$ or around $200 \mathrm{~m} 2$. Land rental prices used for temporary sites are:

- Land rental price per year $=$ IDR. 25,000,000 / year

These costs are sourced from maps.bpn.go.id and interviews with janitors who explain that the location of the polling station in Panggung Lor Village has a price of IDR 125,000 per $\mathrm{m} 2$. Land rental costs are a consideration for the allocation of operational costs for temporary sites to support waste handling activities. Things that need to be considered in the use of rental land for temporary sites is the cleanliness and comfort of the community around the environment, so it does not cause additional negative environmental impacts.

e. Environmental Compensation Cost

The cost of environmental compensation is the cost of providing compensation to people who are negatively affected by the activities of handling waste at a waste processing site concerning. Compensation costs are given to households in temporary locations or existing TPS sites, in the Panggung Lor Village. The number of households or households in Panggung Lor Village is 3,532 households [30]. The compensation fee per family is IDR. 200,000, so the total cost is:

- Cost of environmental compensation = IDR $200,000 \times 3,532 \mathrm{HH}=$ IDR 706,400,000

This fee is aimed at the cost of environmental impact so that the community continues to get services that are suitable for the protection and comfort of waste management activities. This environmental compensation fee is given to each $\mathrm{HH}$ in Kelurahan Panggung Lor for the cost of restoring environmental comfort and health costs. This compensation fee is a form of government responsibility for waste management that can directly impact the community. 
The total cost required for handling flood tidal flood waste is calculated from the overall accumulation of cost items. Cost items consist of the vehicle and heavy equipment costs, labor salary costs, worker operational costs, cleaning equipment costs, tooling costs, support equipment costs, emergency needs costs, first aid costs, land rental costs, and environmental compensation costs. The accumulated costs include, i.e. :

Table 10. Recapitulation of the Total Cost of Tidal Flood Waste Handling Needs (Analysis Results, 2019)

\begin{tabular}{|l|lr|}
\hline \multicolumn{1}{|c|}{ Needs } & \multicolumn{2}{c|}{ Total } \\
\hline $\begin{array}{l}\text { Vehicles and Heavy } \\
\text { Equipment Cost }\end{array}$ & IDR & 8.752 .126 .000 \\
\hline Worker's Salaries Cost & IDR & 3.848 .400 .000 \\
\hline Worker's Operational Cost & IDR & 215.706 .000 \\
\hline Cleaning Equipment Cost & IDR & 105.757 .000 \\
\hline Tools Cost & IDR & 131.712 .000 \\
\hline Supporting Equipment Cost & IDR & 141.034 .000 \\
\hline Emergency Equipment Cost & IDR & 135.876 .000 \\
\hline First Aid Cost & IDR & 150.313 .000 \\
\hline Land Rent Cost & IDR & 25.000 .000 \\
\hline $\begin{array}{l}\text { Environmental Compensation } \\
\text { Cost }\end{array}$ & IDR & 706.400 .000 \\
\hline \multirow{2}{*}{ Total } & IDR 14.209.324.000/year \\
\cline { 2 - 3 } & IDR 1.184.110.333/month \\
\hline
\end{tabular}

\subsection{Unit cost analysis}

Based on the results of the identification of needs and accumulated costs, then these needs will be divided into 2 types of allocation of costs needed in the calculation of the overall needs of flood handling facilities. The types of costs are direct costs and indirect costs. Direct cost and indirect cost analysis aims to classify waste handling needs according to the costs incurred. Direct Cost is the costs incurred directly for waste handling activities, in this case the classification included in the direct costs is the allocation of vehicle and heavy equipment rental costs, operational costs of workers, the cost of buying equipment such as cleaning tools, tools, supporting equipment, emergency equipment, first aid, and salary costs for workers. While indirect costs are costs that are allocated indirectly for the costs of service activities such as administrative costs, insurance, environmental compensation, etc.

The results of the calculation of the overall accumulated costs of handling the need for tidal flood disasters amount to IDR 14,209,324,000/year or as much as IDR $1,184,110,333 /$ month. These costs are costs that are needed starting from the cost of the need for facilities, salary costs, operational costs, to the cost of rent and compensation costs that are used to clean up the tidal flood waste at the affected rob site. The results of the total costs are then calculated per region to get unit costs in the area affected by tidal floods in the District of North Semarang. The area affected by tidal floods is $55.95 \mathrm{Ha}$ or $559,500 \mathrm{~m}^{2}$.

Unit cost calculation is done by dividing the total cost of needs by the area affected by tidal floods, i.e :

$$
\frac{\mathrm{Rp} 1.184 .110 .333}{559.500 \mathrm{~m}^{2}}=\mathrm{Rp} 2.117 / \mathrm{m}^{2}
$$

Thus, the total unit cost per rob area affected by tidal flood waste in North Semarang Sub-District is IDR $2,117 / \mathrm{m}^{2}$. This unit cost is the result of the calculation of the total cost per area and is the unit cost that is borne by the area affected by the flood tidal waste. This is useful to determine the allocation of cost needs to address the issue of tidal flood waste both for direct and indirect cost allocation of needs. Through the calculation of the cost in $\mathrm{m} 2$ or region in the study, it is expected that related parties such as the government and the authorized institutions can prepare a plan for handling tidal flood waste both technically and financially.

\section{Conclusion}

The results of this study use the cost accounting method to calculate the cost of handling tidal flooding in the North Semarang Sub-District, producing an analysis of tidal flooding handling activities, handling needs, to calculating the cost of handling. The total cost needed to handle tidal flood waste in the North Semarang SubDistrict of $+/-70$ tons is IDR $14,209,324,000 /$ year or IDR $1,184,110,333 /$ month. The results of the identification of needs and the accumulation of costs in the form of those needs consist of 2 types of allocation of direct and indirect costs. The results of the total costs are then calculated per region to get unit costs in the area affected by tidal floods in the District of North Semarang. The area affected by tidal floods is $55.95 \mathrm{Ha}$ or $559,500 \mathrm{~m}^{2}$. Thus, the total unit cost per rob area affected by tidal flood waste in North Semarang SubDistrict is IDR $2,117 / \mathrm{m}^{2}$. This cost is a unit cost that is borne by the tidal flood-affected area so that it can be known the allocation of cost needs to overcome the issue of tidal flood waste for both the government and related parties. Through this, the role of government and related institutions/parties is needed. The important thing to note is to formulate a technical planning policy to deal with the impact of disaster waste, especially the handling of tidal flood waste along with technical planning and financial planning.

The research is funded by Directorate General of Research and Development, Ministry of Research, Technology and Higher Education through Institute of Research and Community Services Diponegoro University Fiscal year 2019 with Number 101-147/UN7.P4.3/PP/2019.

\section{References}

1. The Republic of Indonesia President Regulation Number 8 of 2008 on National Disaster Management Agency.

2. S. Kahar, P. Purwanto, W. K. Hidajat, Dampak Penurunan Tanah dan Kenaikan Muka Laut Terhadap Luasan Genangan Rob di 
Semarang, Jurnal Presipitasi: Media Komunikasi dan Pengembangan Teknik Lingkungan, 7(2), 8391. (2011).

3. D. A. Putra, W. Handayani, Kajian Bentuk Adaptasi terhadap Banjir dan Rob Berdasarkan Karakteristik Wilayah dan Aktivitas di Kelurahan Tanjung Mas, Jurnak Teknik PWK, 2 (3). (2013).

4. A.S. Ramadhany, P. Subardjo, A.A.D. Suryo, Daerah Rawan Genangan Rob di Wilayah Semarang, Journal of Marine Research, 1(2), pp.174-180. (2012).

5. S.H. Nugroho, Prediksi luas genangan pasang surut (rob) berdasarkan analisis data spasial di Kota Semarang, Indonesia, Jurnal Lingkungan dan Bencana Geologi, 4(1), pp.71-87. (2013).

6. I. Buchori, A. Sugiri, M. Mussadun, D. Wadley, Y. Liu, A. Pramitasari, I.T. Pamungkas, A predictive model to assess spatial planning in addressing hydro-meteorological hazards: a case study of Semarang City, Indonesia, International journal of disaster risk reduction, 27, 415-426. (2018).

7. G. Handoyo, Suryoputro, A.D Agus, dan P. Subardjo, Genangan Banjir Rob di Kecamatan Semarang Utara, Jurnal Kelautan Tropis, 19 (1): 55-59. (2016).

8. Maryono, Evaluation of Disaster Resilience on Waste Management in Developing Countries. Doctor Disertation, Departement of Urban and Enviromental Engineering, Khusyu University. (2015).

9. C.O. Brown, Disaster Waste Management: a systems approach, University of Canterbury. (2012).

10. J.R. Chen, H.Y. Tsai, P.C. Hsu, C.C. Shen, Estimation of waste generation from floods, Waste management, 27(12), pp.1717-1724. (2007).

11. H. Nakayama, T. Shimaoka, K. Omine, Maryono, P. Patsaraporn, and O. Siriratpiriya, Solid Waste Management in Bangkok at 2011 Thailand Floods, J. Disaster Res., vol. 3, no. 3, pp. 356-346. (2013).

12. Tempo.co. BMKG: Sepekan ke Depan Tinggi Rob Pantura Mencapai 1 Meter. https://nasional.tempo.co/read/782171/bmkgsepekan-ke-depan-tinggi-rob-pantura-mencapai1-meter/full\&view $=$ ok. 8 Juli 2019. (2016).

13. Law No. 18 of 2008 Regarding Waste Management.

14. N. Aida, Eksternalitas (Negatif) dan Lingkungan Hidup, JAMSWAP, 1(1), pp.88-94. (2009).

15. D.N. Hyman, Public finance: A contemporary application of theory to policy, Cengage Learning. (2014).

16. A. Ruban, E.I.K. Putri, Ekayani, Willingness to Pay Masyarakat Terhadap Pengolahan Sampah Ramah Lingkungan di TPA Dusun Toisapu Kota Ambon, Journal of Agriculture, Resource and Environmental Economics, 1(1). (2014).

17. Atlantic Coastal Action Program (ACAP), Handbook on Environmental Economics, Environment Canada Atlantic Region. Dartmouth. (1996).
18. United States Environmental Protection Agency (EPA), Cost Accounting for Municipal Solid Waste Management: A Handbook, EPA 530-R-95-041. Washington DC. (1997).

19. AACE, International Recommended Practice No.10S-90 Cost Engineering Terminology Tcm Framework: General Reference, Association for the Advancement of Cost Engineering International. (2010).

20. S. Debnath, S.K. Bose, Exploring full cost accounting approach to evaluate cost of MSW services in India, Resources, Conservation and Recycling, 83, pp.87-95. (2014).

21. Maryono, H. Nakayama, and T. Shimaoka, 'Identification of Factors Affecting Stakeholders' Intentions to Promote Preparedness in Disaster Waste Management: A Structural Equation Modeling Approach', J. Mem. Fac. Eng. Kyushu Univ., 74, no. 3, pp. 79-98. (2015).

22. T. Tabata, Y. Wakabayashi, P. Tsai, T. Saeki, Environmental and Economic Evaluation of PreDisaster Plans for Disaster Waste Management: Case Study of Minami-Ise, Japan, Waste Management, 61, 386-396. (2017).

23. C. Brown, M. Milke, Recycling Disaster Waste: Feasibility, Method, and Effectiveness. Journal Resources, Conservation, and Recycling 106, 2132. (2016).

24. National Institute for Environmental Studies (NIES). Flood Waste Management Guidelines for Bangkok. Center for Material Cycles and Waste Management Research National Institute for Environmental Studies (NIES). Ibaraki. (2015).

25. National Disaster Management Agency Regulation No. 2 of 2014 concerning Guidelines for Implementing Use of Disaster Management Special Equipment.

26. Regulation of the Minister of Public Works of the Republic of Indonesia No.03/PRT/M/2013 Regarding the Implementation of Infrastructure and Solid Waste Facilities in Handling Household and Similar Waste.

27. Regulation of the Minister of Manpower and Transmigration of the Republic of Indonesia No PER.08/MEN/VII/2010 Regarding Personal Protective Equipment (PPE).

28. Regulation of the Minister of Manpower and Transmigration of the Republic of Indonesia No.PER.15/MEN/VIII/2008 Regarding First Aid in Accidents at the Workplace.

29. Sustainable Heritage Network (SHN). Disaster Response Equipment. https://sustainableheritagenetwork.org/digitalheritage/disaster-response-equipment-checklist. 18 Juli 2019. (2013).

30. Central Statistics Agency on North Semarang SubDistrict in Figures year 2018. 